\title{
Seasonal Changes of Nutrient Concentrations in Water of Some Locations in Southern Iraqi Marshes, After Restoration.
}

\author{
Mohammed A. H. Al-Kenzawi \\ Date of acceptance 22/3/2009
}

\begin{abstract}
After restoration of Iraqi marshes during 2003, three locations were chosen, one in each main marsh (Um Al-Naaj site in Al-Hwaizeh marsh; Al-Nagarah site in AlHammar marsh and Al-Baghdadia site in Al-Chebaysh marsh) to determine the concentrations of nutrients (Nitrate, Nitrite, Phosphate and Silicate) in water seasonally for the period winter, spring, summer, and autumn at 2007. Five water replicates were collected from each site, seasonally. In the Lab., the samples were analyzed by colorimetric methods; the results showed that Um-Al-Naaj site has the highest nutrients level, while Al-Nagarah site has the lowest level. The statistical program t-test was applied at the significant levels $(P$-value $<0.01)$ and $(P$-value $<$ $0.05)$ to know the significant differences in the nutrients concentration among the sites, as well as among the seasons. Statistically, the results showed that $\mathrm{NO}_{3}, \mathrm{NO}_{2}$, and $\mathrm{PO}_{4}$ concentrations have significant differences among the sites, as well as among the seasons. While, $\mathrm{SiO}_{2}$ concentrations have no significant differences among the sites, but they differed significantly among the seasons.
\end{abstract}

Key words: Changes, Nutrients, Iraqi Marshes.

\section{Introduction}

The Tigris and Euphrates rivers have created about $15,000 \mathrm{~km}^{2}$ of wetlands known as the Mesopotamian marshes. These wetlands comprise a complex of interconnected shallow freshwater lakes and marshlands and are considered the most extensive wetland ecosystem in the Middle East [1, 2]. Water levels reach their maximum in early spring and then fall by as much as two meters during the hot dry summer [3, 4]. The larger wetlands within this complex ecosystem are: (a) the Al-Hammar and its associated marches south of the Euphrates, (b) the Central Marshes, a vast complex of permanent lakes and marshes north of the Euphrates and west of the Tigris, and (c) the Al-Hawizeh and its associated marshes extending east from the Tigris into neighboring Iran.

Within the last few years, major hydrological engineering activities in and around the area of Lower Mesopotamia have resulted in the drying out of vast areas of wetlands in the Central Marshes and Al-Hammar, and could eventually lead to the disappearance of these systems [5]. Currently, less than $10 \%$ of the marshlands in Iraq remain as fully functioning wetlands because of the extensive drainage and upstream agricultural irrigation programs on the Tigris and Euphrates rivers[6]. Now, restoration by re-flooding of drained marshes is proceeding in the Central and Al-Hammar marshlands [7].

*Biology Department, College of Science for Women, University of Baghdad. 


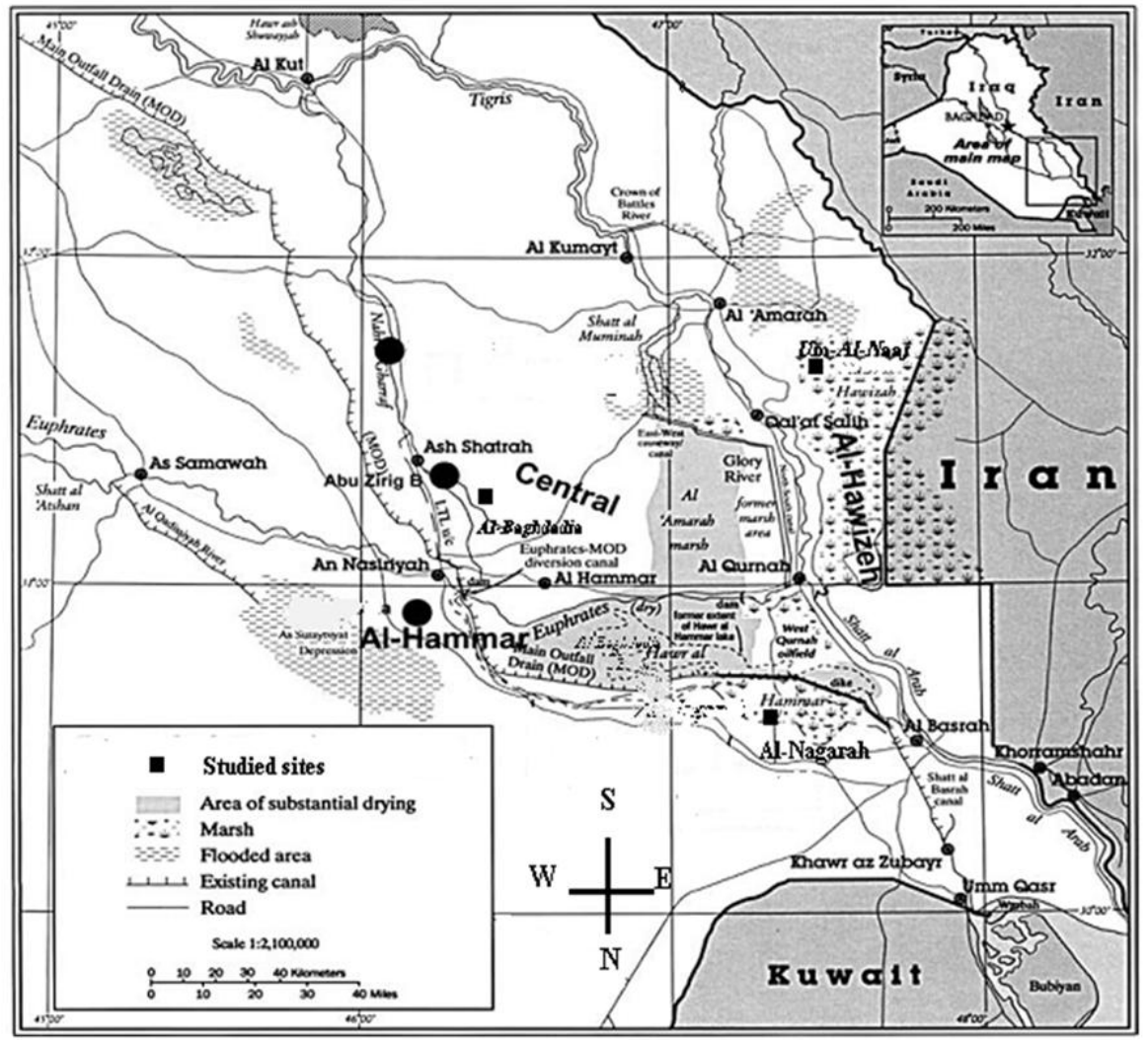

Fig.(1): Locations map of the studied sites [8].

Nutrients availability in wetlands is determined by sediment and watershed characteristics as well as hydrology [9].

Nutrients, especially nitrates and phosphates represented as principal parameters in the aquatic environment, they are important factors for primary productivity and phytoplankton growth, which represents the base of pyramid in the food chain [10]. There are different sources of nutrients in the aquatic environment, some represent human activities such as using fertilizers for vegetation in agriculture as well as living organisms wastes, and the other source is the degradation residuals of living organism bodies. The later source represents the major source for enrichment of marshlands with nutrients [11].

Nutrient bioassays are useful indicators as to which nutrient has the potential or is likely to limit phytoplankton and aquatic plant growth at a particulate time and space [12]; Nitrogen is the most abundant nutrient in commercial fertilizers. It enters the water from human and animal waste and runoff of fertilizer from lawns and crops [13]

Many studies were conducted for the estimation of nutrients in the marshlands among which are $[14,15$, 16].

Most of previous studies focused upon the relation between levels of nutrients and growth of phytoplankton 
in Al-Hammar marsh. [13] determined levels of nutrients in Central marsh. Al-Hawiezah marsh did not receive any attention due to difficulties and instability [11].

After restoration, there is little studies deal with relationship between nutrients and phytoplankton [17], interaction between nutrients and benthic macroinvertebrates [13], these in Abu-Zirig marshes, and [15] studied the relationship between nutrients and diversity and productivity of aquatic macrophytes in the Central Iraqi marshes.

Therefore, interdisciplinary studies are necessary and essential, especially during the restoration operations that are currently taking place. The main objective of this study is to determine the levels of nutrients in the waters of southern Iraqi marshlands including three locations, in Al-Chebaysh, AlHammar, and Al-Hawiezah marshes.

\section{Materials and Methods}

During the four seasons of 2007; Jan. - Dec., subsurface water samples were collected from the three selected sites in southern Iraqi marshes, which are shown in figure -1-. Water samples were transferred to the laboratory and kept in fridge for analysis. In the laboratory, nutrients were determined according to colorimetric methods, which are explained in APHA.

The statistical significance of difference for data among sites was assessed using t-test. $P$-value less than the point 0.01 and 0.05 level of significance were considered statistically significant [18]. In addition, Mean, Standard Error, and Standard Deviation were calculated.

\section{Results}

The concentrations of nutrients (nitrite, nitrate, phosphate and silicate) were determined during winter, spring, summer and autumn, at the year 2007 in water from Iraqi marshlands, these are clear in the figures $(2,3,4$, and 5$)$.

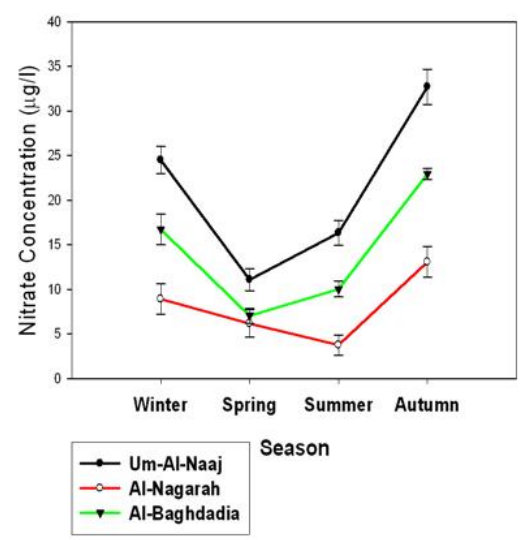

Fig.(2): Seasonal changes in nitrate concentrations with standard error.

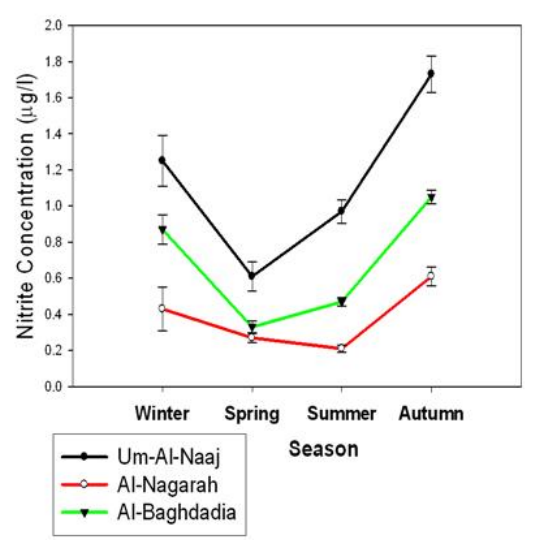

Fig. (3): Seasonal changes in nitrite concentrations with standard error.. 


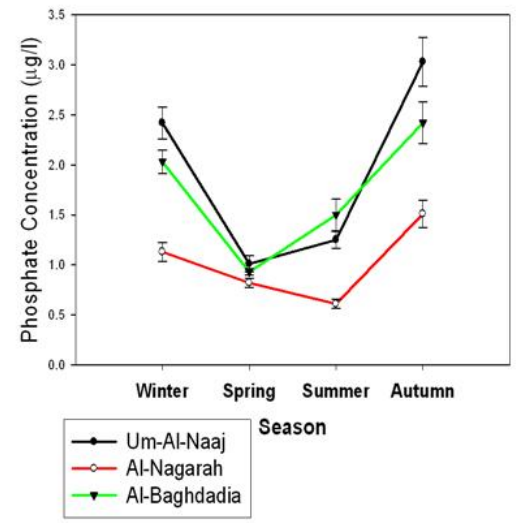

Fig. (4): Seasonal changes in phosphate concentrations with standard error.

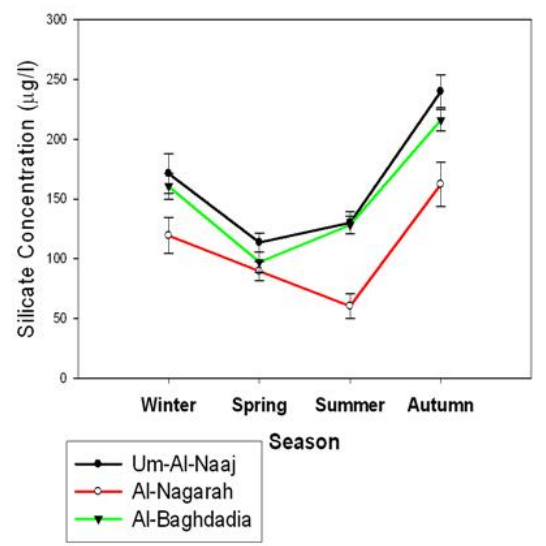

Fig. (5): Seasonal changes in silicate concentrations with standard error.

Statistically, the results showed that $\mathrm{NO}_{3} \quad$ concentration differed significantly at $(P<0.01$ and $P<0.05)$ between Um-Al-Naaj and Al-Nagarah stations; also, there are significant differences at $(P<0.05)$ between winter and spring, thus between spring and autumn. $\mathrm{NO}_{2}$ concentrations have significant differences at $(P<0.05)$ between Um-Al-Naaj and Al-Nagarah stations, while there is significant difference at $(P<0.01$ and $P<0.05)$ between Al-Nagarah and AlBaghdadia stations; on the other hand, there are significant differences at $(P<$ $0.05)$ between its concentration at spring and summer, also between spring and autumn. $\mathrm{PO}_{4}$ concentrations have significant differences at $(P<$ 0.01 and $P<0.05$ ) between Um-AlNaaj and Al-Nagarah stations, while there is significant difference at $(P<$ 0.05 ) between Um-Al-Naaj and AlBaghdadia stations; on the other hand, there are significant differences at $(P<$ 0.01 and $P<0.05$ ) between winter and spring, spring and summer, thus spring and autumn. There are no significant differences in $\mathrm{SiO}_{2}$ concentrations among the stations, but there are significant differences at $(P<0.05)$ in its concentration between spring and summer, also between spring and autumn. See tables 1 and 2 .

Table (1): A summary of t-test results showing the significant differences for nutrient concentrations by $P$-value at significant levels 0.01 and 0.05 , among the studied stations.

\begin{tabular}{|c|c|c|c|c|}
\hline \multirow[t]{2}{*}{ Site } & \multicolumn{4}{|c|}{$\begin{array}{l}P \text {-value for Nutrient } \\
\text { concentrations }\end{array}$} \\
\hline & $\mathrm{NO}_{3}$ & $\mathrm{NO}_{2}$ & $\mathrm{PO}_{4}$ & $\mathrm{SiO}_{2}$ \\
\hline $\begin{array}{l}\text { Um-Al-Naaj and Al- } \\
\text { Nagarah }\end{array}$ & $0.009^{*}$ & 0.011 & $\begin{array}{c}0.000 \\
* *\end{array}$ & - \\
\hline $\begin{array}{c}\text { Al-Nagarah and Al- } \\
\text { Baghdadia }\end{array}$ & - & $\begin{array}{c}0.009 \\
* *\end{array}$ & - & - \\
\hline $\begin{array}{l}\text { Um-Al-Naaj and Al- } \\
\text { Baghdadia }\end{array}$ & - & - & $\begin{array}{c}0.045 \\
* *\end{array}$ & - \\
\hline
\end{tabular}

Table (2): A summary of t-test results showing the significant differences for nutrient concentrations by $P$-value at significant levels 0.01 and 0.05 , among the seasons.

\begin{tabular}{|c|c|c|c|c|}
\hline \multirow{2}{*}{ Season } & \multicolumn{4}{|c|}{$\begin{array}{c}\text {-value for Nutrient } \\
\text { concentrations }\end{array}$} \\
\cline { 2 - 5 } & $\mathrm{NO}_{3}$ & $\mathrm{NO}_{2}$ & $\mathbf{P O}_{4}$ & $\mathbf{S i O}_{2}$ \\
\hline $\begin{array}{c}\text { Winter and } \\
\text { Spring }\end{array}$ & $0.013^{*}$ & - & $\begin{array}{c}0.002 \\
* *\end{array}$ & - \\
\hline $\begin{array}{c}\text { Spring and } \\
\text { Autumn }\end{array}$ & $0.023^{*}$ & $\begin{array}{c}0.013 \\
*\end{array}$ & $\begin{array}{c}0.001 \\
* *\end{array}$ & $\begin{array}{c}0.047 \\
*\end{array}$ \\
\hline $\begin{array}{c}\text { Spring and } \\
\text { Summer }\end{array}$ & - & $\begin{array}{c}* .042 \\
*\end{array}$ & $\begin{array}{c}0.007 \\
* *\end{array}$ & $\begin{array}{c}0.014 \\
*\end{array}$ \\
\hline
\end{tabular}




\section{Discussion}

Nutrients come from precipitation and dry atmospheric deposition as well as the weathering of rocks and minerals and the decomposition of organic matter [9].

Nitrogen is the most abundant nutrient in commercial fertilizers. It enters the water from human and animal waste and runoff of fertilizer from lawns and crops [19].

The results of the present study showed that the nitrate and nitrite concentration values in water were present with low concentrations in all of the studied marshes at spring and summer, while the highest values were at winter and autumn. The significant differences in $\mathrm{NO}_{3}$ and $\mathrm{NO}_{2}$ concentrations might be due to increasing the solubility of the organic materials at winter and autumn [20,21]. As well as, increasing of number of aquatic plant growth and diversity that should be led to decrease the concentrations to become in the lowest values at spring and summer. In addition, abundance of phytoplankton and zooplankton that led for consuming more amounts from these nutrients $[15,22]$. As well as, increasing the water levels at winter by rain leads to bring more of nutrient with it to the marsh[15].

In aquatic environment, phosphorus is considered one from main important nutritious components to aquatic plants, phytoplankton, and zooplankton[17]. The results of the present study showed that the reactive phosphate concentrations were low at the study period, this agrees with the previous studies $[15,17,23]$, that may be attributed to the pollution sources, which have reactive phosphate, is few.

The high significant differences in the reactive phosphate concentration may be because the amounts of reactive phosphate that are taken up by aquatic plants, phytoplankton and other aquatic organisms do not affect their concentrations at winter, clearly. As well as, releasing amounts of reactive phosphate from the bottom sediments to water and degradation of aquatic plants, phytoplankton and others organic matter from the bottom, that lead for increasing the reactive phosphate concentrations at autumn, this agrees with $[13,15,17]$. While the low reactive phosphate concentrations were in spring and summer, in the all of three marshes that agrees with[16, 23]. Whereas the diversity and growth of aquatic plants and phytoplankton blooming should be increased in spring and summer so that more amounts from reactive phosphate is taken up in metabolic process $[15,17]$.

Concentrations of silicate in natural water have too much importance in increasing the number of aquatic organisms, especially diatoms, the silicate shares in building of their body structure, and plays important role in diatoms productivity [24].

The significant differences in silicate concentrations that may be due to the rain, when it brings with it more silicate from the neighbor soils and edges that should be led for increasing silicate concentration in the marsh at winter[25]. As well as, its increasing at autumn that may be because increasing water temperature that should be led to degradation of diatoms, and the dead aquatic plants and another aquatic organisms, finally that should be caused releasing it from sediment to water $[13,17]$. While the reducing of silicate concentrations in spring and summer that may be due to increasing the growth and numbers of diatoms, Algae and aquatic macrophytes, which consume more amounts from silicate $[15,25]$.

Statistically, there are significant differences in concentrations of $\mathrm{NO}_{3}$, $\mathrm{NO}_{2}$ and $\mathrm{PO}_{4}$ among the studied sites that because Um-Al-Naaj marsh has 
nutrients concentrations more than other two stations that may be due to this marsh has large parts did not exposure to dry during $1990 \mathrm{~s}$, that should be led to this marsh has more organic matter (which is source of nutrients in water) because it has more biodiversity than other marshes, this agrees with other studies $[15,23]$. While Al-Nagharah marsh has nutrient less than other two stations that may be because this marsh was exposed to dry during 1990s and it is affected by Shatt Al-Arab tidal, so that it exposed for washing and dilution continuously [15]. Nevertheless, there are no significant differences in $\mathrm{SiO}_{2}$ concentrations among the studied sites that because its concentration is high in all of studied sites that may be due to its big amounts, which are added to water by degradation process for dead organisms at warm period, also its concentrations that enter to the marshes with rain water and what are transported it by erosion process from the margin areas $[23,26]$.

\section{Conclusion}

This study concluded that the waters of southern Iraqi marshlands are rich in nutrients specially nitrates and silicates which enhance their suitability for growth and blooming of aquatic plants and phytoplankton which are necessary for primary productivity in marshlands water and food chain for different aquatic organisms. As well as, the highest nutrients concentrations were in winter and autumn, while the lowest concentrations were in spring and summer. In addition, the marsh that has more nutrients concentrations was UmAl-Naaj, while the marsh that has less nutrients concentrations was AlNagarah.

\section{References:}

1- Brasington, J., Nicholson, E., and Clark, P. 2002. The Iraqi marshlands: a human and environmental study. Politics Publishing, London. Pp. 76-102.

2- Partow, H. 2001. Demise of an ecosystem: the disappearance of the Mesopotamian Marshlands United Nations Environment Program (UNEP). Publication UNEP/DEWA/TR. 01-3, Nairobi, Kenya.

3- Al-Saadi, H.A., Antoin,S.E. and Nural-Islam, A.K.M. 1981. Limnological investigation in AlHammar marsh area in southern Iraq. Journal of Nova Hedweigia. 35:157-166.

4- Talling, J.F. and Rzoska, J. 1980. Water characteristics. In: (ed) Euphrates and Tigris, the Mesopotamian ecology and density. (ed. J. Rzoska). W. Jank, The Hague, Boston and London. Pp. 122-129.

5- Richardson, C.J., Reiss, P., Hussain, N. A., Alwash, A. J., Pool, D. J. 2005. The restoration of potential of the Mesopotamian marshes of Iraq. Journal of Science. 307:13071311.

6- Lawler, A. 2005. Reviving Iraq's wetlands. Journal of Science. 307:1186-1189.

7- Hussein, N.A. and Taher, M.A. 2007. Effect of daily variations, diurnal fluctuations and tidal stage on water parameters of East Hammar marshland, Southern Iraq. Journal of Marsh Bulletin. 2(1): 32-42.

8- Rushdi, A. I., DouAbul, A. A., Mohammed, S. S. and Simoneit, B. R. T. 2006. Compositions and sources of extractable organic matter in Mesopotamian marshland surface sediments of Iraq. I: aliphatic lipids. Journal of Environ Geol. 50: 857-866. 
9- Cronk, J.K. and Fennessy, M.S. 2001. Wetland Plants Biology and Ecology. CRC Press LLC. pp. 462.

10- Wetzel, R.G. and Likens,G.E. 2000. "Limnological Analysis".3rd ed. Springer Verlag, New York Inc. pp. 429.

11- Al-Mausawi,A. H. and Hussain, N. A. 1991. Physico - Chemical parameters of southern Iraqi Marshes. Preliminary report presented to Marine Science Center, University of Basrah.

12- Ault, T., Velzeboer, R. and Zammit, R. 2000. Influence of nutrient availability on phytoplankton growth and community structure in the Port Adelaide River, Australia: Bioassay assessment of potential nutrient limitation. Journal of Hydrobiologia. 42 (9): 89-103.

13- Al-Saffar, M.A.T. 2006. Interaction between the environmental variables and benthic macroinvertebrates community structure in Abu-Zirig Marsh, Southern Iraq. M.Sc. Thesis, University of Baghdad, Iraq, pp. 156

14- Al-Lami, A. A. 1986. Limnological study for phytoplankton of some southern Iraqi marshes. M. Sc. Thesis, College of Science, University of Basrah, Iraq. pp. 144.

15- Al-Kenzawi, M. A. H. 2007. Ecological study of aquatic macrophytes in the central part of the marshes of Southern Iraq. Baghdad University-College of Science for Women, Iraq, pp. 270.

16- Kassim, T. I. 1986. Limnological study for benthic algae in some marshes, southern Iraq. M. Sc. Thesis, College of Science, University of Basrah, Iraq. pp. 203.

17- Al-Obaidi, G.S.A. 2006. A Study of phytoplankton community in
Abu Zirig marsh, Southern Iraq. M.Sc. Thesis, University of Baghdad, Iraq, pp. 102.

18- Sorlie, D.E. 1995. Medical Biostatistician and Epidemiology: examination and board review. $1^{\text {st }}$ d. Appleton and Lang, Norwalk, Connecticut. pp. 193.

19- Camargo, J.A., Alonso, A. and De La Puente, M. 2004. Multimetric assessment of nutrient enrichment in impounded rivers based on benthic macroinvertebrates. Journal of Environmental Monitoring and Assessment. 96: 233-249.

20- Al-Suaige, R.A. 1999. Comparative limnological study for Shatt Al-Arab estuary and Al-Khora canal. M.Sc. Thesis, University of Basrah, Iraq, pp. 141.

21- Hussein, S.A., Al-Essa, S.A. and Al-Manshad, H.N. 2000. Limnological Investigations to the Lower Reaches of Saddam River. Environmental characteristics. Basrah. Journal of Agriculture. 13(2): 25-37.

22- Maulood, B.K., Hinton, G.C.F., Kamees, H.S., Saleh, F.A.K., Shaban, A.A. and Al-Shahwani, S.M.H. 1979. An ecological survey of some aquatic ecosystems in southern Iraq. Journal of Tropical Ecology. 20(1): 27-40.

23- Adam, R.S., Al-Shawi, I.J.M., and Al-Imarah, F.J.M. 2007. Distribution of some chemical elements in the marsh lands of Southern Iraq after rehabilitation. Journal of Marsh Bulletin. 2(1): 11-17.

24- Goldman, C.P. and Horne, A.L. 1983. Limnology Mc Groaw-Hill international book company, pp. 464.

25-Al-Aaraji, M. J. 1988. Limnological study for phytoplankton and nutrients in Hor Al-Hammar, Iraq. 
M. Sc. Thesis, College of Science, University of Basrah, Iraq, pp. 113. 26-Al-Manshad, H.N.A. 1998. Primary productivity in Southern part of
Saddam River, Iraq. M.Sc. Thesis, University of Basrah, Iraq, pp. 145.

\section{التغيرات الموسمية لتركيز المغذيات في مياه بعض مناطق اهوار جنوب العراق، بعد اعادة التأهيل \\ محمد عبالزرضا حدان الكنزاوي*}

|قتسم علوم الحياة، كلية العلوم لللبنات، جامعة بغداد

الكلمات المفتاحية: تغيرات. المغذيات. الأهوار العراقية.

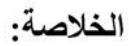

بعد اعادة تأهيل الأهوار العر اقية سنة 2003، اختيرت ثثلاث مواقع، واحد في كل هور رئيس. أم النعاج في الني

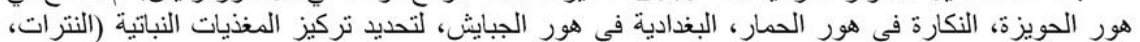

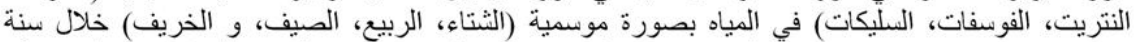

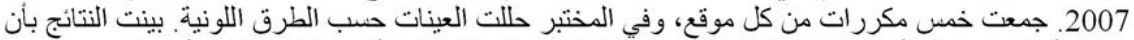

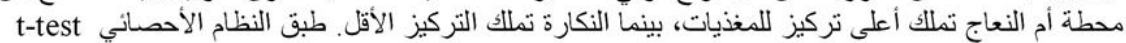

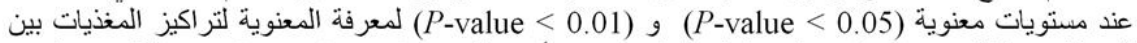
المحطات وكذلك بين المواسم. احصائيا، النتائج بينت بأن تراكيز NO3

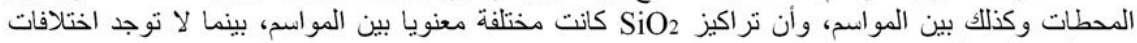
معنوية بين المحطات 